\title{
Collaborative Governance : Proyek Penyelenggaraan Jaringan Tulang Punggung Serat Optik Palapa Ring di Indonesia Tahun 2016-2019
}

\author{
${ }^{1}$ Sri Oniwati Susanti, ${ }^{2}$ Vishnu Juwono \\ ${ }^{12}$ Program Studi Administrasi dan Kebijakan Publik, Fakultas Ilmu Administrasi \\ Universitas Indonesia, Depok, Indonesia \\ Email :onesanti47@gmail.com,vjuwono@ui.ac.id \\ Received: 28 April 2019; Revised: 17 Mei 2019; Accepted: 30 Juni 2019
}

\begin{abstract}
The digital divide in Indonesia is a wicked problem that requires a collaborative process to solve it. In this case, the government implements a National Strategic Project consisting of the construction Palapa Ring's optical fiber backbone network infrastructure that uses the concept of PPP (Government and Business Entity Cooperation). This study aims to analyze how to manage the collaborative governance of the Palapa Ring's Project. The research method used was qualitative descriptive with post positivist that used the collaborative governance theory of Emerson and Nabatchi (2015) as knife analysis. The results showed that based on the results of the research and discussion it could be concluded that the collaborative governance process in the Palapa Ring Optical Fiber Backbone Network Implementation Project in Indonesia had not run optimally because there are several dimension of collaboration that have not been well fulfilled. The recommendation for the next study is that collaborative research also looks at the outcomes of ongoing infrastructure development.
\end{abstract}

Keyword: Collaborative governance; Palapa Ring; Telecommunication infrastructure

\begin{abstract}
Abstrak
Kesenjangan digital di Indonesia merupakan wicked problem yang membutuhkan proses kolaborasi dalam penyelesaiannya. Terkait dengan permasalahan tersebut, pemerintah menyelenggarakan Proyek Strategis Nasional berupa pembangunan infrastruktur jaringan tulang punggung serat optik Palapa Ring yang menggunakan konsep KPBU (Kerja Sama Pemerintah dan Badan Usaha). Penelitian ini bertujuan untuk menganalisa bagaimana penerapan tata kelola kolaboratif proyek penyelenggaraan jaringan tulang punggung serat optik Palapa Ring yang telah berjalan selama tahun 2016 - 2019 . Metode penelitian yang digunakan adalah kualitatif dengan pendekatan post positivist yang menggunakan teori tata kelola kolaboratif Emerson dan Nabatchi (2015) sebagai pisau analisis. Hasil penelitian menunjukkan bahwa proses collaborative governance dalam Proyek Penyelenggaraan Jaringan Tulang Punggung Serat Optik Palapa Ring di Indonesia belum berjalan secara maksimal karena terdapat beberapa dimensi kolaborasi yang belum terpenuhi dengan baik. Rekomendasi untuk penelitian berikutnya adalah selain melihat dari sisi collaboration dynamics, peneliti juga melihat dari sisi outcome pembangunan infrastruktur yang telah berjalan.
\end{abstract}

Kata kunci: Tata kelola kolaboratif; Palapa Ring; Telekomunikasi

Link DOI : http://dx.doi.org/10.31314/pjia.8.1.12-23.2019

12 Copyright (C) 2019, Publik (Jurnal Ilmu Administrasi), Under the license CC BY-SA 4.0 ISSN: 2301-573X (Print), ISSN: 2581-2084 (Online) 


\section{PENDAHULUAN}

Teknologi

\section{Informasi}

dan

Komunikasi (TIK) merupakan wadah penyebaran informasi di era globalisasi ini. TIK yang kemudian merujuk kepada penggunaan internet saat ini merupakan sesuatu yang sangat krusial dan menjadi salah satu penopang pembangunan dalam menghadapi permasalahan seperti kemiskinan, keterbelakangan informasi, dan kebodohan. Dari hasil survey APJII (Asosiasi Penyelenggara Jasa Internet Indonesia) seperti yang ditunjukkan pada gambar 1, terjadi kenaikan yang signifikan yaitu sebesar 55,16\% dari tahun 20142017, pada tahun 2017 jumlah pengguna internet di Indonesia mencapai 143,26 juta jiwa atau $54,68 \%$ dari total populasi penduduk Indonesia.

Namun, peningkatan tersebut tidak sebanding dengan pemerataan penggunaan internet di Indonesia. Penyebaran penggunaan internet masih sangat timpang antara wilayah Indonesia bagian barat dengan Indonesia bagian timur. Komposisi pengguna internet di wilayah Jawa mencapai 58,08\%, sementara komposisi pengguna internet di wilayah MalukuPapua hanya mencapai 2,49\%.

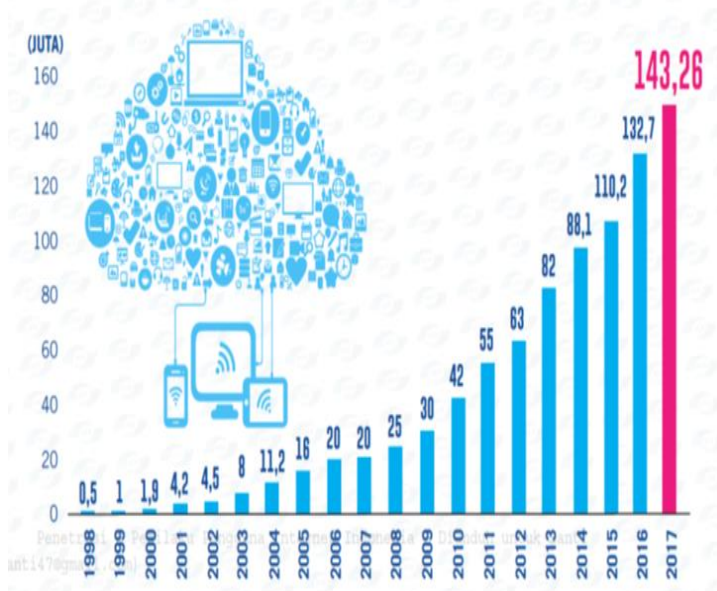

Sumber : APJII, 2017.

Gambar 1. Pertumbuhan Pengguna Internet di Indonesia

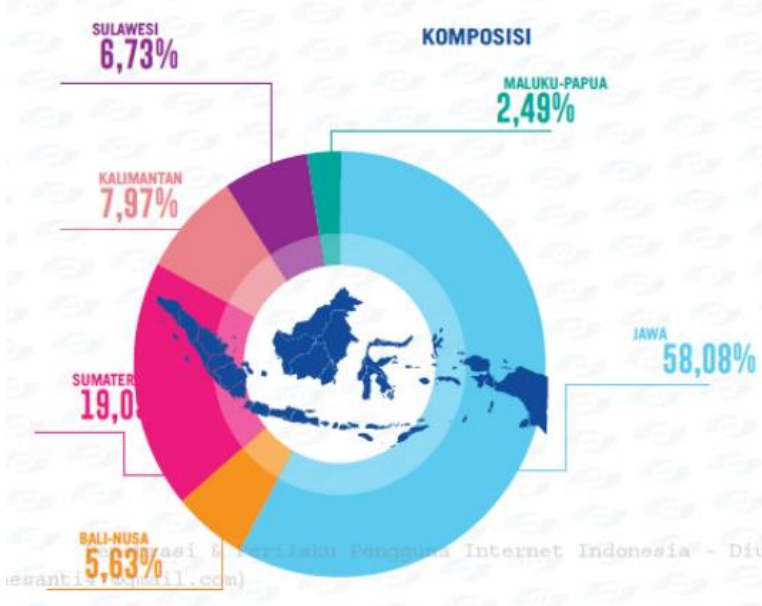

Sumber : APJII, 2017.

Gambar 2. Komposisi Pengguna Internet Berdasarkan Wilayah

Di Indonesia, yang memiliki topografi wilayah hutan, pegunungan, lembah, dan perbukitan, khususnya wilayah 3T (tertinggal, terluar, dan terdepan) yang mengakibatkan sulit dan mahalnya pembangunan infrastruktur telekomunikasi. sehingga operator swasta pun enggan untuk membangun infrastruktur di wilayah tersebut. Nilai kesenjangan digital di propinsi Indonesia paling besar dimiliki oleh propinsi Papua, Nusa Tenggara Timur, dan Sulawesi Tengah, hal tersebut disebabkan masih rendahnya pembangunan infrastruktur telekomunikasi dan kemampuan/skill penduduk di propinsi tersebut masih tergolong rendah (Ariyanti, 2015).

Sejak tahun 1998, pemerintah Indonesia telah berupaya untuk membangun infrastruktur telekomunikasi di daerah yang tidak terjamah oleh operator. Pada saat itu, mulai direncanakan pembangunan infrastruktur telekomunikasi yang diberi nama Nusantara 21, akan tetapi proyek tersebut tidak berjalan dengan baik karena adanya krisis moneter. Kemudian pada event Infrastructure Summit I pada tahun 2015, wacana pembangunan infrastruktur telekomunikasi tersebut kembali dibahas dan didengungkan mengenai Cincin Serat Optik Nasional 
(CSO-N) yang merupakan jaringan kabel kasar bawah laut membentuk cincin berisikan frekuensi pitalebar yang terintegrasi membentang dari Sumatera hingga Papua, saat ini dikenal dengan Palapa Ring. Pelaksanaan pembangunan infrastruktur jaringan tulang punggung serat optik Palapa Ring memperhitungkan pembangunan pada daerah non komersil demi pemerataan akses pitalebar di Indonesia.

Permasalahan kesenjangan digital merupakan salah satu masalah sosial atau wicked problem yang bersifat multidimensi karena memiliki keterkaitan dengan ekonomi, pendidikan, politik, sosial budaya, dan lain sebagainya. Oleh karena itu, untuk memecahkan permasalahan tersebut dibutuhkan tata kelola yang bersifat integratif dan kolaboratif. Pemerintah dapat melibatkan stakeholders non pemerintah dalam membuat dan mengimplementasikan kebijakan publik (Ansell \& Gash, 2008). Hal tersebut juga diungkapkan oleh Emerson dan Nabatchi (2015) bahwa tata kelola kolaboratif meliputi kemitraan antar negara, swasta, masyarakat, serta gabungan antara pemerintah dan non pemerintah seperti kemitraan publik-swasta atau kemitraan swasta-sosial atau co-management regimes.

Pemerintah dituntut untuk melakukan penyesuaian terhadap perkembangan global yang mencakup internal organisasi pemerintah, namun juga eksternal organisasi yang menuntut pemerintah agar menjadi lebih fleksibel, dan peran pemerintah dituntut bisa mewadahi semua kepentingan dalam sebuah kerangka demokrasi (Haryono, 2012). Collaborative Governance merupakan sebuah wacana baru dalam memahami eksistensi stakeholders kebijakan publik, ada karakteristik antar hubungan aktor dan stakeholders sehingga diperlukan adanya studi kolaborasi (Silvia, 2011). Collaborative Governance menurut Ansel dan Gash (2008) adalah cara pengelolaan pemerintahan yang melibatkan stakeholders secara langsung, berorientasi pada konsensus, dan musyawarah dalam proses pengambilan keputusan secara kolektif yang bertujuan merencanakan dan melaksanakan kebijakan publik.

Junus (2010) berpendapat bahwa kolaborasi adalah metode yang digunakan untuk menggabungkan beberapa organisasi atau individu untuk meningkatkan kemampuan dari adanya keterbatasan sumberdaya, melalui beberapa cara yaitu : memperbaiki atau mengembangkan keuntungan dari suatu kegiatan melalui usaha bersama, proses membangun hubungan antar kekuasaan untuk mengambil keputusan dalam suatu kegiatan, saling tukar informasi, membagi sumber daya, dan mengembangkan kapasitas dalam mencapai tujuan yang disepakati bersama.

Kolaborasi baik dalam jenis kontrak, kemitraan, atau jaringan, mengubah dinamika tata kelola hubungan aktor utama dalam administrasi publik. Kolaborasi melibatkan interaksi antara dua aktor yaitu manajer publik (pemerintah) dan kolaborator yang terlibat dengan manajer publik (Forrer et al., 2014). Untuk pelaksanaan pembangunan infrastruktur Palapa Ring tersebut, Kementerian Komunikasi dan Informatika memilih sebuah mekanisme yang memungkinkan pihak pemerintah untuk bekerja sama dengan badan usaha berdasarkan Peraturan Presiden Nomor 38 Tahun 2015 tentang Kerja Sama Pemerintah dengan Badan Usaha dalam Penyediaan Infrastruktur. Adapun struktur kolaborasi proyek 
penyelenggaraan jaringan tulang punggung serat optik Palapa Ring menerapkan skema KPBU (Kerja Sama Pemerintah dengan Badan Usaha) yang digambarkan pada gambar 3, dengan sistem pembayaran Availability Payment (AP) dengan sumber dana proyek yang berasal dari dana Universal Service Obligation (USO).

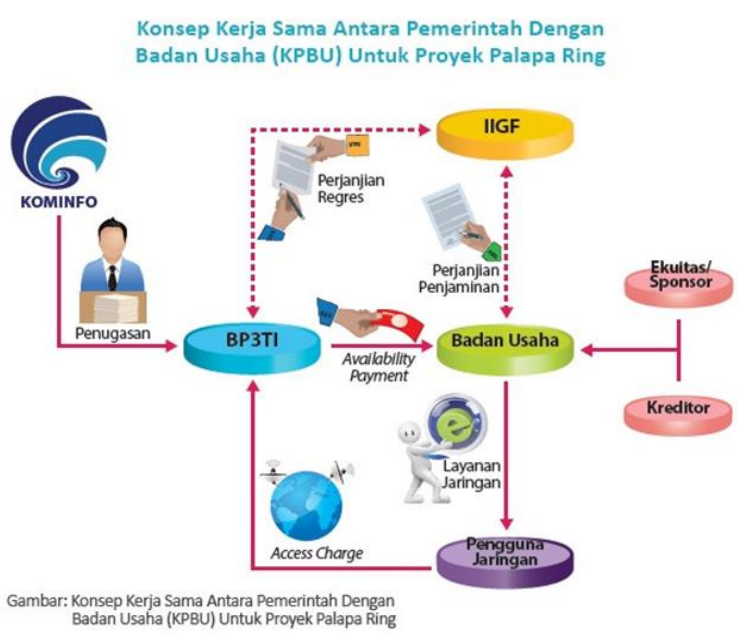

Sumber : Humas BP3TI Kominfo, 2016.

Gambar 3. Bagan Konsep KPBU Proyek Palapa Ring

Penelitian sebelumnya terkait penerapan tata kelola kolaboratif yaitu penelitian yang dilakukan oleh Jing dan Li (2018) berjudul "Private Roles in Enhancing Multi-level Governance: China's Internet+ National Strategy" yang dipublikasikan dalam Public Policy and Administration SAGE Journal. Penelitian tersebut mengangkat studi kasus kebijakan Pemerintah Cina yaitu proyek strategi nasional Internet+ dengan melihat dari sisi bagaimana keterlibatan swasta dalam perencanaan dan implementasi kebijakan pemerintah. Persamaan penelitian Jing dan Li dengan penelitian ini adalah sama-sama mengangkat kebijakan strategis nasional pemerintah dengan melihat dari sisi tata kelola kolaborasinya. Sedangkan perbedaannya adalah dari penggunaan teori tata kelola kolaborasi dan perbedaan negara, penelitian Jing dan Li tersebut menggunakan acuan teori kolaborasi Donahue dan Zeckhauser (2011) dengan melihat 4 (empat) jenis faktor yang mempengaruhi kolaborasi yaitu : informasi, nilai/pengetahuan. legitimasi, dan kapasitas operasional, sementara penelitian ini menggunakan acuan teori kolaborasi Emerson dan Nabatchi (2015). Hasil yang diperoleh dalam penelitian tersebut menyebutkan bahwa pemerintah Cina mempunyai konsistensi dalam membentuk keterlibatan aktor-aktor eksternal dan multi level government (MLG) dapat terjadi dimana hubungan antar pemerintah dan aktor non pemerintah tidak sepenuhnya setara.

Persamaan penelitian Jing dan Li dengan penelitian ini adalah sama-sama mengangkat kebijakan strategis nasional pemerintah dengan melihat dari sisi tata kelola kolaborasinya. Perbedaan dengan penelitian Jing dan Li dari model atau tata kelola kolaborasi yang digunakan dan perbedaan negara, Jing dan Li meneliti kebijakan pemerintah Cina sementara dalam penelitian ini meneliti kebijakan pemerintah Indonesia, kedua negara tersebut sama-sama negara berkembang, namun Cina merupakan negara dengan pengguna internet terbesar di dunia (Kompas.com, 2018).

Sedangkan, untuk penelitian terkait Palapa Ring pernah dilakukan oleh Rosalia Adisti, mahasiswi Delft University dalam thesisnya yang berjudul "Human Development Impact of The Implementation of Broadband : A Case Study of The Indonesian Palapa Ring Project". Adisti (2017) menggunakan pendekatan penelitian kualitatif eksploratif. Tujuan penelitian tersebut adalah membangun pengetahuan dan wawasan tentang penilaian dampak pembangunan 
manusia dari adanya implementasi broadband dengan studi kasus proyek Palapa Ring Indonesia. Penelitian Adisti (2017) difokuskan pada wilayah Nusa Tenggara (dimana broadband MKCS (Mataram-Kupang Cable System) yang dibangun oleh Telkom telah diimplementasikan di wilayah tersebut sejak tahun 2009) dan wilayah Papua (yang telah dimasuki broadband serat optik SMPCS (Sulawesi-Maluku-Papua Cable System) yang dibangun oleh Telkom pada tahun 2016). Adisti (2017) menggunakan model UNDP Human Development Impact Assessment (HDIA) yang membagi 4 pilar pembangunan manusia yaitu : produktivitas, kesetaraan (equality), keberlanjutan (sustainability), dan pemberdayaan (empowerment).

Adapun hasil penelitian Adisti (2017) adalah dari pilar produktivitas, dampak positif akan berpengaruh di bidang kesehatan (dari penggunaan e-health, penggunaan broadband untuk pencegahan penyakit dan kampanye kesehatan), pendidikan (e-education, akses ke materi online), dan pendapatan (dukungan untuk bisnis dan perorangan/rumah tangga), tetapi juga akan mungkin berdampak negatif pada potensi kesalahan informasi dan mental individu (misalnya kecanduan terkait internet, cyberbullying); dari pilar equality, Palapa Ring mungkin memenuhi tugasnya untuk membawa kesetaraan di seluruh kota, namun ada kemungkinan lebih banyak ketidaksetaraan secara geografis di luar kota (misalnya daerah pedesaan) dan lintas kelompok sosial; sementara di pilar sustainability, penggunaan broadband ke depannya akan berperan dalam menyebarkan kesadaran tentang masalah lingkungan, namun di sisi lain, dengan adanya penggunaan broadband konsumsi karbon kemungkinan akan meningkat. Dampak negatif lain yang mungkin terjadi di masyarakat yaitu radikalisme, penipuan, dan berita palsu; dari pilar empowerment, penggunaan broadband diharapkan memberikan dampak positif pada kebebasan dan keterlibatan politik, kebebasan informasi, dan kebebasan berpendapat. Di bidang pemerintahan, hal tersebut membuat akuntabilitas pemerintah lebih transparan. Persamaan dari penelitian ini adalah samasama mengangkat tema kebijakan Palapa Ring sebagai subjek penelitian. Sementara perbedaannya adalah dalam penelitiannya tersebut, Adisti mengangkat tema dampak pembangunan manusia dengan menggunakan model HDIA UNDP dalam kerangka pemikirannya sementara dalam penelitian ini mengangkat tema tata kelola kolaboratif dengan menggunakan model Collaborative Governance Emerson et al. (2015).

Tujuan dari penelitian ini adalah untuk menganalisa bagaimana penerapan tata kelola kolaboratif proyek penyelenggaraan jaringan tulang punggung serat optik Palapa Ring yang telah berjalan dalam rentang waktu tahun 2016 - 2019. Manfaat dari penelitian ini adalah dari sisi praktisi, diharapkan dapat menjadi masukan dan rujukan bagi para pemangku kebijakan untuk mengoptimalkan tata kelola kolaboratif. Sedangkan dari sisi akademisi, hasil penelitian ini dapat memberikan sumbangan pikiran guna menambah referensi dalam pengembangan Ilmu Administrasi dan Kebijakan Publik pada kebijakan sektor Teknologi Informasi dan Komunikasi (TIK).

\section{METODE PENELITIAN}

Metode penelitian yang digunakan adalah deskriptif kualitatif dengan pendekatan post positivist. Penelitian ini 
mengeksplorasi fenomena yang terjadi dengan mendeskripsikan variabel dan komponen yang berkenaan dengan tata kelola kolaboratif. Penelitian deskriptif memberikan gambaraan yang spesifik dari situasi, social setting, atau sebuah hubungan (Neuman, 2003). Metode pengumpulan data yang digunakan adalah wawancara mendalam, studi literatur dan observasi lapangan.

Lokasi penelitian ini antara lain di wilayah DKI Jakarta (Kantor Kementerian Kominfo dan BAKTI), Kep. Sangihe dan Kep. Natuna (Kantor Pemerintah Daerah). Analisis data pada pendekatan kualitatif merupakan upaya yang dilakukan dengan jalan bekerja dengan data, memilah-milah menjadi kesatuan yang dapat dikelola, mensintesiskan, mencari dan menemukan pola, menemukan apa yang penting dan apa yang harus dipelajari untuk memutuskan apa yang akan dijadikan kesimpulan dalam penelitian (Moleong, 2017).

Pisau analisis yang digunakan dalam penelitian ini adalah teori Collaborative Governance Emerson dan Nabatchi (2015) yang mengungkapkan bahwa tindakan kolaborasi secara mendasar merupakan proses berbentuk siklus, adanya interaksi yang dilakukan dengan meningkatkan komunikasi yang baik, pemahaman bersama, pergerakan prinsip bersama (principled engangement), motivasi bersama (shared motivation), serta kapasitas untuk melakukan tindakan bersama (capacity for joint action). Kerangka kerja tata kelola kolaboratif yang dikembangkan oleh Emerson dan Nabatchi (2015) digambarkan dalam gambar 4.

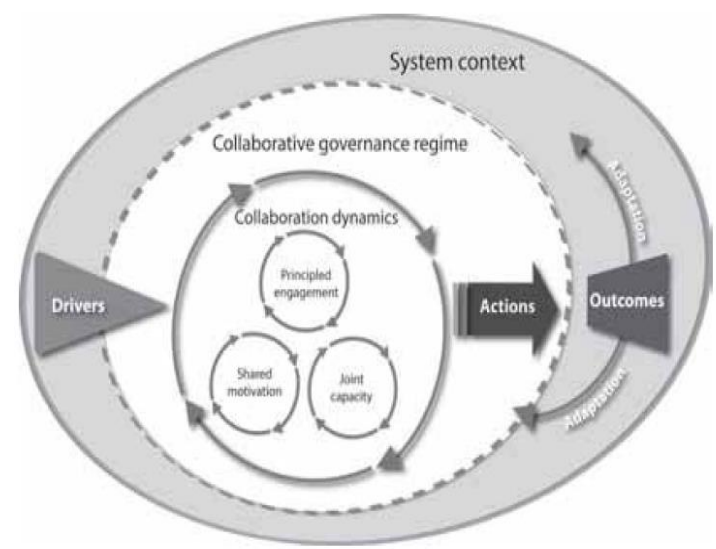

Sumber : Emerson dan Nabatchi, 2015.

\section{Gambar 4 Kerangka Tata Kelola} Kolaboratif

\section{HASIL DAN PEMBAHASAN}

Faktor-faktor yang mempengaruhi proses tata kelola kolaboratif proyek penyelenggaraan jaringan tulang punggung serat optik Palapa Ring

a. System Context

Collaborative

Governance

diinisiasi dan berkembang dalam konteks yang berlapis antara politik, kerangka hukum, kondisi sosial ekonomi, lingkungan, dan pengaruh lainnya (Emerson dan Nabatchi, 2015). Sebelum terbentuknya sistem KPBU Palapa Ring, kegiatan dalam penanggulangan kesenjangan digital dilakukan dalam proyek kerjasama konvensional, dimana Kementerian Komunikasi dan Informatika memikul semua tanggung jawab mulai dari perencanaan hingga pendanaan, tidak ada share risiko antara pihak pemerintah dengan swasta. Sebagai leading sector bidang komunikasi dan informatika, Kementerian Komunikasi dan Informatika berperan cukup besar terkait dengan program pengentasan kesenjangan digital di Indonesia. BP3TI (Balai Penyedia dan Pengelola Pembiayaan Telekomunikasi dan Informatika) atau saat ini dikenal sebagai BAKTI (Badan Aksesbilitas Telekomunikasi dan Informasi) yang 
merupakan Badan Layanan Umum dibawah Kementerian Komunikasi dan Informatika mempunyai peran dalam penyediaan infrastruktur dan ekosistem di cakupan wilayah 3T (Terpencil, Terluar, dan Tertinggal). Sebagai institusi yang mengintegrasikan proses kolaborasi, Kementerian Komunikasi dan Informatika memiliki tanggung jawab untuk mengkoordinasikan seluruh aktor dalam lingkup kolaborasi proyek Palapa Ring ini. Operator swasta dan badan usaha menjadi mitra yang penting dalam kolaborasi ini, mereka memiliki sumber daya dan skill yang saling melengkapi dalam proses pembangunaninfrastruktur telekomunikasi.

Dari sisi kerangka hukum (policy and legal framework), kerangka kebijakan dan hukum, memungkinkan dan membatasi pengambilan keputusan dan tindakan pribadi tetapi juga sistem kerja dari Collaborative Governance Regime (CGR) (Bryson, Crosby, dan Stone, 2006). Terdapat beberapa peraturan yang melatarbelakangi adanya kolaborasi dalam pembangunan infrastruktur Palapa Ring ini diantaranya adalah :

- Peraturan Presiden Nomor 38 Tahun 2015 tentang Kerja sama Pemerintah dengan Badan Usaha dalam Penyediaan Infrastruktur

- Peraturan Menteri Negara

Perencanaan Pembangunan

Nasional/Badan Perencanaan

Pembangunan Nasional Nomor 4 Tahun 2015 tentang Tata Cara Pelaksanaan Kerja sama Pemerintah dengan Badan Usaha dalam Penyediaan Infrastruktur

- Peraturan Presiden Republik Indonesia Nomor 78 Tahun 2010 tentang Penjaminan Infrastruktur dalam Proyek Kerja Sama Pemerintah dengan Badan Usaha yang Dilakukan
Melalui Badan Usaha Penjaminan Infrastruktur

Dalam peraturan-peraturan di atas dijelaskan dan diatur mengenai peran PJPK sebagai leader kolaborasi, PMU (Project Management Unit), dan peran aktor kolaborasi lainnya. Kemudian dari peraturan-peraturan tersebut diturunkan lagi ke dalam MoU dan Perjanjian Kerja Sama (PKS) yang bersifat mengikat antar anggota kolaborasi. MoU dan Perjanjian Kerjasama tersebut telah disepakati untuk pelaksanaan kolaborasi sampai dengan tahun 2033. Kerangka hukum yang sudah terbentuk ini menjadi dasar kolaborasi dan mempengaruhi proses kolaborasi selanjutnya.

Dari sisi sosial ekonomi dan budaya, adanya kesenjangan digital di Indonesia identik dengan masalah sosial ekonomi dan budaya. Pengentasan kesenjangan digital dibutuhkan peran serta dari berbagai pemangku kepentingan. Para aktor kolaborasi yang merupakan gabungan antara pihak pemerintah dan swasta memiliki budaya kerja yang berbeda. Pemerintah memiliki kultur birokratif, sementara Badan Usaha Penyelenggara (BUP) yang merupakan pihak swasta tidak terlalu rigid. Namun, hal tersebut tidak menjadi penghalang bagi proses kolaborasi. Keduanya melakukan penyesuaian agar kolaborasi tetap berjalan. Justru dengan adanya kolaborasi, terjadi adopsi secara perlahan antara budaya kerja swasta ke dalam budaya kerja pemerintah.

Dari sisi karakteristik jaringan, dinamika politik dan hubungan kekuasaan, proyek pembangunan Palapa Ring sangat erat dengan ketiga hal tersebut, berdasarkan informasi dari narasumber, dimana awal pelaksanaan Proyek Palapa Ring sempat terhambat selama beberapa tahun dikarenakan adanya dinamika politik 
internal organisasi dan adanya perubahan struktur kerja sama yang akan digunakan.

Dari sisi Level of Conflict/Trust, terdapat perbedaan motif antara masingmasing aktor kolaborasi. Di satu sisi pemerintah ingin membangun infrastruktur telekomunikasi di wilayah non komersil 3T, namun di sisi lain Badan Usaha Penyelenggara (BUP) menginginkan wilayah komersil untuk meningkatkan profit. Namun, perbedaan motif tersebut mendorong antusiasme masing-masing aktor untuk melakukan kolaborasi, dimana pemerintah berkolaborasi dengan BUP dan operator untuk meningkatkan PK (Pencapaian Kinerja) sementara BUP berkolaborasi dengan pemerintah untuk mendapatkan Availability Payment (AP) dari pembangunan Palapa Ring ini.

\section{b. Drivers}

Dari sisi Leadership yang menginisiasi proses kolaborasi untuk pembangunan Palapa Ring, perencanaan pembangunan Palapa Ring yang tertuang di Peraturan Presiden Nomor 96 Tahun 2014 diinisiasi oleh Pemerintahan SBY. Kemudian, inisiasi tersebut diteruskan oleh pemimpin berikutnya yaitu pada masa pemerintahan Jokowi. Dan pada masa pemerintahan Jokowi ditetapkan skema yang pas dimana terdapat pembagian risiko antara pemerintah dan swasta. Menteri Kominfo ditunjuk sebagai Penanggung Jawab Proyek Kerjasama (PJPK).

Adanya ketidakpastian akan keberlanjutan dari program kerja terkait pengentasan kesenjangan digital yang terjadi sebelumnya, misalnya Program MPLIK yang hanya beroperasi selama setahun dan tidak ada penanganan keberlanjutan atas program tersebut, sehingga anggaran yang dikeluarkan menjadi sia-sia dan tidak ada outcome yang bisa dirasakan oleh masyarakat, sehingga memicu para aktor kolaborasi
KPBU Proyek Palapa Ring untuk duduk bersama dan mendorong terjadinya ketergantungan antar aktor untuk memastikan bahwa infrastruktur yang dibangun memiliki keberlanjutan dalam jangka panjang dan menghasilkan outcome yang signifikan bagi pengentasan kesenjangan digital di Indonesia. Untuk mengantisipasi uncertainty dalam pembangunan Palapa Ring, dilakukan filterisasi dan kajian yang lebih mendalam sebelum proyek pembangunan Palapa Ring dimulai.

Masing-masing aktor kolaborasi mendapatkan Consequential Incentives atas keberlangsungan proses kolaborasi, dimana pemerintah akan mendapatkan peningkatan nilai Raport Instansi yang tertuang dalam Laporan Akuntabilitas Kinerja Instansi Pemerintah) dan di satu sisi BUP akan mendapatkan Availability Payment (AP) dan peningkatan nilai perusahaan jika berhasil dalam pembangunan proyek Palapa Ring.

Terdapat ketergantungan (interdependence) yang tergambarkan dalam pembangunan Palapa Ring ini, dimana pemerintah tidak dapat bergerak sendiri dalam pembangunan Palapa Ring dikarenakan adanya keterbatasan sumber daya dan BUP tidak dapat melakukan pembangunan tanpa adanya kesediaan lahan dan perizinan dari pemerintah. Adanya ketergantungan tersebut sehingga memicu masing-masing pihak untuk melakukan kolaborasi.

Penerapan Collaboration Dynamics dalam proyek penyelenggaraan jaringan tulang punggung serat optik Palapa Ring a. Principled engagement

Dari sisi discovery, mengacu pada adanya perbedaan kepentingan yang diungkapkan kemudian diidentifikasi dan dianalisis untuk selanjutnya dijadikan trigger dalam menyatukan tujuan utama 
dalam kolaborasi. Kasus adanya kesenjangan digital di Indonesia memerlukan upaya kolaboratif dalam pengentasannya. Sebagai upaya untuk mewadahi koordinasi lintas sektoral, Presiden menunjuk Kementerian Komunikasi dan Informatika sebagai institusi yang berfungsi untuk memimpin, mengelola, mengkoordinasikan, dan mengevaluasi seluruh kegiatan pembangunan infrastruktur Palapa Ring sebagai tulang punggung jaringan serat optik yang nantinya akan memudahkan akses internet ke seluruh wilayah. Regulasi berupa Peraturan Presiden Nomor 38 Tahun 2015 tentang Kerja sama Pemerintah dengan Badan Usaha dalam Penyediaan Infrastruktur dan Peraturan Menteri Negara Perencanaan Pembangunan Nasional/Badan Perencanaan Pembangunan Nasional Nomor 4 Tahun 2015 tentang Tata Cara Pelaksanaan Kerja sama Pemerintah dengan Badan Usaha dalam Penyediaan Infrastruktur, yang memuat mengenai tugas dan wewenang anggota kolaborasi.

Setelah adanya discovery, pendefinisian mengenai konsep infrastruktur Palapa Ring pada seluruh aktor yang terlibat dalam kolaborasi merupakan salah satu upaya untuk menyamakan persepsi mengenai apa yang dibutuhkan dan perlu dikembangkan dalam pembangunan infrastruktur Palapa Ring ini. Deliberasi atau musyawarah merupakan bagian dari proses komunikasi. Dalam hal ini, dalam proses kolaborasi Palapa Ring, BP3TI atau BAKTI memfasilitasi proses deliberasi dengan mengadakan Forum Group Discussion dan Meeting yang rutin dilaksanakan seminggu sekali. Unsur determinasi yang difasilitasi dalam pertemuan formil dimana pertemuan lebih membahas mengenai masalah teknis dan progress dari pembangunan yang telah dilaksanakan. Walaupun sudah ada Peraturan Pemerintah yang mendasari kolaborasi dari sistem KPBU, namun belum ada aturan khusus setingkat Peraturan Menteri atau SK yang membahas mengenai pembagian tugas para aktor yang terlibat dalam Proyek Palapa Ring, pembagian kerja khusus yang ada hanya tertuang dalam Perjanjian Kerja Sama (PKS).

Terkait dengan kesepakatan bersama, terdapat beberapa hal yang diputuskan oleh pemerintah tanpa melibatkan aktor kolaborasi lain sehingga menjadi pemicu adanya konflik dalam pemanfaatan jaringan last mile Palapa Ring, misalnya mengenai penetapan Tarif Palapa Ring. Hal tersebut menimbulkan dampak pada enggannya operator untuk menggunakan fasilitas Palapa Ring yang dianggap kurang menguntungkan.

\section{b. Shared motivation}

Motivasi memiliki peranan dalam proses kolaborasi, dimana motivasi dapat menjadi faktor pendorong untuk mencapai tujuan kolaborasi. Shared motivation didasari oleh unsur mutual trust, shared understanding, internal legitimacy, dan shared commitment. Pada unsur mutual trust atau rasa saling percaya, dalam kolaborasi KPBU Proyek Palapa Ring ini, masing-masing aktor membangun kerpercayaan dengan cara masing-masing. Kementerian Komunikasi dan Informatika percaya terhadap kinerja Badan Usaha Penyelenggara (BUP), karena sebelum terlibat dengan Proyek Palapa Ring, Induk dari salah satu BUP PT. LEN Telekomunikasi Indonesia yaitu PT. Len Industri telah membuktikan kinerjanya melalui program kerja dari proyek sebelumnya seperti misalnya Proyek ITTS 


\section{Available Online at http://journal.umgo.ac.id/index.php/Publik \\ Publik (Jurnal Ilmu Administrasi) Vol 8 (1), Juni 2019}

II dan Proyek Pembangunan Pemancar TV

Digital. Kepercayaan pemerintah diperkuat dengan adanya bukti track record Badan Usaha dan Surat Pernyataan Minat (Expression of Interest) pada saat proses prakualifikasi pengadaan. Kemudian BUP pun membangun kepercayaan kepada pemerintah, karena pemerintah menginisiasi adanya penjaminan dalam proyek Palapa Ring ini dengan melibatkan PT. Penjaminan Infrastruktr Indonesia. Rasa saling percaya antar instansi pemerintah dan Badan Usaha tersebut muncul dari adanya pertemuan bersama, pelaksanaan program kerja, evaluasi kegiatan, dan pengambilan keputusan.

Adanya mutual trust kemudian menghasilkan mutual understanding yang kemudian akan mempengaruhi keberlangsungan pembangunan infrastruktur yang telah direncanakan. Hal tersebut juga diperkuat dengan adanya legitimasi internal yang berupa pengakuan dari internal organisasi pada masingmasing aktor kolaborasi dalam KPBU Palapa Ring ini. Seperti BUP yang merupakan konsolidasi dari beberapa anak perusahaan, mendapatkan dukungan dari perusahaan induk masing-masing untuk terlibat dalam pembangunan Palapa Ring ini. Legitimasi internal ini ditemukan melalui adanya pertemuan bersama, pengalaman kerjasama, dan adanya hubungan di luar kolaborasi.

$$
\text { Legitimasi internal tersebut }
$$
kemudian membentuk sebuah komitmen yang terwujud dalam sebuah Memorandum of Understanding (MoU) atau Surat Perjanjian Kerjasama.

\section{c. Capacity for joint action}

Kapasitas untuk melakukan aksi bersama merupakan aspek ketiga dari dinamika kolaborasi yang merupakan aspek ketiga dari dinamika kolaborasi yang merupakan hasil dari keterlibatan Copyright (C) 2019, Publik (Jurnal Ilmu Administrasi), Under the license CC BY-SA 4.0 ISSN: 2301-573X (Print), ISSN: 2581-2084 (Online) berprinsip dan motivasi bersama. Kapasitas untuk melakukan aksi bersama terdiri dari elemen prosedur dan kesepakatan institusi (procedural and institutional arrangements), kepemimpinan (leadership), pengetahuan (knowledge), dan sumber daya (resource).

Dari sisi prosedur dan kesepakatan institusi (procedural and institutional arrangements), dalam kolaborasi KPBU Palapa Ring yang melibatkan instansi antar pemerintah, swasta, dan BUMN diformulasikan melalui Peraturan Presiden Nomor 38 Tahun 2015 tentang Kerja sama Pemerintah dengan Badan Usaha dalam Penyediaan Infrastruktur, namun landasan hukum tersebut bersifat KPBU secara umum. Pengikatan antar aktor kolaborasi dan pembagian kerja tercantum dalam Memorandum of Understanding $(M o U)$ dan Surat Perjanjian Kerja Sama, belum adanya Surat Keputusan atau Peraturan Menteri yang mengatur aksi dan peran antar aktor kolaborasi khusus untuk KPBU Palapa Ring.

Dari sisi leadership, kepemimpinan dalam kolaborasi lebih merujuk kepada jaringan daripada berbentuk hierarkis, semua aktor dalam kolaborasi berada pada posisi yang sama. Kepemimpinan juga mampu meredam konflik yang setiap saat dapat terjadi dalam forum kolaboratif (Sahar, 2019). Menteri Komunikasi dan Informatika sebagai leader kolaborasi yang berfungsi sebagai koordinator, pendukung, fasilitator, mediator, dan peran lainnya. Proyek Palapa Ring tidak akan berjalan jika tidak dipegang oleh leader kolaborasi yang memiliki kompetensi kepemimpinan yang baik. Berdasarkan informasi yang didapat dari narasumber, dalam proyek Palapa Ring ini, Menteri Kominfo turut andil dalam mengevaluasi progress pembangunan Palapa Ring dan turut andil dalam pengecekan langsung ke lapangan demi memastikan bahwa pembangunan 
infrastruktur tersebut telah berjalan dengan baik.

Dalam melakukan aksi bersama, pengetahuan tentang kebutuhan infrastruktur telekomunikasi di daerah tertinggal, terdepan, dan terluar Indonesia merupakan hal yang perlu dipahami bersama. Tiap aktor yang terlibat dalam kolaborasi KPBU Proyek Palapa Ring ini memiliki karakteristik pengetahuan yang berbeda-beda. Distribusi pengetahuan antar aktor kolaborasi sudah sejalan. Pertemuan rutin yang dilakukan secara berkala antar aktor kolaborasi membentuk koordinasi dan komunikasi yang transparan dan intensif.

Dari sisi resources, aktor kolaborasi memberikan dukungan yang maksimal untuk keberhasilan pembangunan Palapa Ring ini, seperti Sumber Daya Manusia (SDM), anggaran (BAKTI dan Kementerian Kominfo menggunakan anggaran KPU USO untuk membiayai proyek Palapa Ring ini, serta Badan Usaha Penyelenggara yang mendapat pembiayaan dari kreditur sindikasi), dan Sumber Daya Alam (Pemerintah Daerah yang menghibahkan tanah untuk lokasi pembangunan terminal station Palapa Ring).

\section{PENUTUP}

\section{Kesimpulan}

Hasil penelitian menunjukkan bahwa proses tata kelola kolaboratif dalam KPBU Palapa Ring sudah berjalan cukup baik namun belum maksimal. Terdapat beberapa dimensi kolaborasi yang perlu dibenahi, seperti dimensi principled engangement, pelibatan aktor kolaborasi untuk kesepakatan bersama yang masih perlu ditingkatkan, khususnya untuk pemanfaatan jaringan last mile karena nantinya akan berdampak pada outcome.
Kemudian dimensi capacity for joint action yang sudah terbentuk, namun masih diperlukan adanya Surat Keputusan atau Peraturan Menteri yang mengatur aksi dan peran antar aktor kolaborasi khusus untuk KPBU Palapa Ring. Di sisi lain, leader kolaborasi yang merupakan PJPK dalam KPBU Palapa Ring sudah menunjukkan perannya secara maksimal dengan terus melakukan pemantauan dan evaluasi rutin terhadap progress pembangunan Palapa Ring. Dinamika kolaborasi terus berjalan dimulai dari proses perencanaan, pembangunan, hingga proses pemeliharaan. Setelah pembangunan selesai, dinamika kolaborasi selanjutnya akan makin meluas dengan melibatkan operator untuk mengaktifkan jaringan last mile Palapa Ring.

\section{Saran}

Untuk penelitian selanjutnya diharapkan proses kolaborasi yang diteliti tidak hanya terbatas pada collaboration dynamicsnya saja tapi juga melihat sampai ke outcome dari pembangunan infrastruktur yang telah berjalan (untuk outcome baru dapat dinilai ketika infrastruktur tersebut minimal telah 2 tahun digunakan oleh masyarakat).

\section{DAFTAR PUSTAKA}

Adisti, Rosalia. (2017). Human Development Impact of The Implementation of Broadband : A Case Study of The Indonesian Palapa Ring Project. (Thesis). Delft : Delft University of Technology.

Ansell, C., \& Gash, A. (2008). Collaborative governance in theory and practice. Journal of Public Administration Research and Theory. https://doi.org/10.1093/jopart/mum0 32 


\section{Available Online at http://journal.umgo.ac.id/index.php/Publik}

Publik (Jurnal Ilmu Administrasi) Vol 8 (1), Juni 2019

Ariyanti, S. (2015). Studi Pengukuran Digital Divide di Indonesia. Buletin Pos dan Telekomunikasi. https://doi.org/10.17933/bpostel.201 3.110402

Asosiasi Penyelenggara Jasa Internet Indonesia (APJII). (2017). Infografis Penetrasi dan Perilaku Pengguna Internet Indonesia : Survey 2017.

Bryson, J. M., Crosby, B. C., \& Stone, M. M. (2006). The Design and Implementation of Cross-Sector Collaborations: Propositions from The Literature. Public Administration Review. https://doi.org/10.1111/j.15406210.2006.00665.x

Donahue, J. D., \& Zeckhauser, R. (2011). Collaborative governance: private roles for public goals in turbulent times. In Collaborative governance: private roles for public goals in turbulent times.

Forrer, John J., Kee, James Edwin, dan Boyer, Eric. (2014). Governing Cross-Sector Collaboration. San Fransisco : Jossey-Bass.

Haryono, N. (2012). Jejaring Untuk Membangun Kolaborasi Sektor Publik. Jurnal Jejaring Administrasi Publik.

Jing, Yijia, dan Li, Danyao, Li. (2018). Private Roles in Enhancing Multilevel Governance : China's "Internet+" National Strategy. Public Policy and Administration SAGE Journal 0(0) : 1-21.

Neuman, William Lawrence. (2003). Social Research Methods : Qualitative and Quantitative Approaches (Fifth Edition). USA : Pearson Education Inc.

Pertiwi, Wahyunanda Kusuma. (2018, Agustus 27). Pengguna Internet di China Tembus 802 Juta Orang. Kompas.com, 3 Maret 2019.

Copyright (C) 2019, Publik (Jurnal Ilmu Administrasi), Under the license CC BY-SA 4.0 ISSN: 2301-573X (Print), ISSN: 2581-2084 (Online) https://tekno.kompas.com/read/2018/ 08/27/10340017/pengguna-internetdi-china-tembus-802-juta-orang.

Provan, Keith G, Amy Fish, and Joerg Sydow. (2007). Interorganizational Networks at the Network Level: A Review of the Empirical Literature on Whole Networks. Journal of Management, 33 (3): 479-516.

Moleong, L. J. (2017). Metodologi Penelitian Kualitatif (Edisi Revisi). Bandung: PT. Remaja Rosda Karya.

Sahar, Abdul Rasyid. (2019). Tata Kelola Kolaboratif Dalam Penanggulangan Kemiskinan di Kabupaten Pinrang. (Thesis Program Studi Ilmu Administrasi dan Kebijakan Publik). Depok : Universitas Indonesia.

Silvia, Chris. (2011). Collaborrative Governance Concepts for Succesful Network Leadership. State and Local Government Review from SAGE Publication. Vol. 43 (1), hal. 66-71. 